\title{
PENGELOMPOKAN KASUS PENYAKIT AIDS BERDASARKAN PROVINSI DENGAN DATA MINING K-MEDOIDS CLUSTERING
}

\author{
Leonardo Purba ${ }^{1}$, Saifullah ${ }^{2}$, Rafiqa Dewi ${ }^{3}$ \\ ${ }^{1}$ Mahasiswa Program Studi Sistem Informasi STIKOM Tunas Bangsa Pematang Siantar \\ ${ }^{2,3}$ STIKOM Tunas Bangsa Pematangsiantar, Indonesia \\ Email: ${ }^{1}$ leopurba1203@gmail.com, ${ }^{2}$ Saifullah@amiktunasbangsa.ac.id, ${ }^{3}$ rafiqa@ amiktunasbangsa.ac.id
}

\begin{abstract}
Abstrak
Acquired Immunodeficiency Syndrome atau Acquired Immune Deficiency Syndrome (disingkat AIDS) adalah sekumpulan gejala dan infeksi yang timbul karena rusaknya sistem kekebalan tubuh manusia akibat infeksi virus HIV. Penelitian ini membahas tentang Aplikasi Rapidminer dalam Pengelompokkan Kasus Penyakit AIDS berdasarkan Provinsi dengan Data Mining Kmedoid Clastering. Kenaikan kasus AIDS di Indonesia menjadi kasus yang tidak pernah lepas dari perhatian pemerintah. Perhatian dengan tingkat kematian yang terus meningkat membuat orang kuatir dengan penyebaran virus AIDS ini. Sumber Data dan penelitian ini dikumpulkan dari dokumen keterangan Jumlah Desa/Kelurahan Yang Memiliki Sarana Kesehatan yang dihasilkan oleh Badan Penyelenggara Jaminan Sosial. Data yang digunakan dalam penelitian ini yaitu data dari tahun 2008-2011 yang terdiri dari 34 provinsi. Kriteria penilaian yang digunakan sebanyak 2 yakni 1). rata-rata jumlah kasus penyakit AIDS dan 2) rata-rata jumlah meninggal kasus penyakit AIDS yang dikelola menggunakan 2 cluster yaitu tingkat cluster tinggi (C1), dan tingkat cluster rendah (C2). Sehingga diperoleh penilaian cluster C1 untuk Kasus Penyakit AIDS berdasarkan Provinsi sebanyak 4 provinsi yaitu Papua, DKI Jakarta, Jawa Barat dan Jawa Timur, 9 provinsi untuk cluster C2. Hal ini dapat menjadi masukan kepada pemerintah, provinsi yang menjadi perhatian dalam jumlah kasus penyakit AIDS.
\end{abstract}

Kata Kunci: Data Maining, Penyakit AIDS, Clustering, K-medoid

\begin{abstract}
Acquired Immunodeficiency Syndrome or Acquired Immune Deficiency Syndrome (AIDS abbreviated) is a set of symptoms and infections that arise due to the destruction of the human immune system due to HIV viral infection. This study discusses about Rapidminer Application in Grouping Cases of AIDS Disease by Province with K-medoid Clustering Data Mining. The rise of AIDS cases in Indonesia has become a case that never escapes government attention. Attention to the ever increasing rate of death makes people worry about the spread of the AIDS virus. Sources of data and research are collected from the information document Number of Villages Who Have Health Facilities produced by the Social Security Administering Board. The data used in this study is data from 2008-2011 which consists of 34 provinces. Assessment criteria used are 2 ie 1). the average number of AIDS cases and 2). the average number of AIDS cases deaths were managed using 3 clusters ie high cluster level (C1), medium cluster level (C2) and low cluster level (C3). So that the cluster C1 obtained for Cases of AIDS Disease by Province as many as 4 provinces of Papua, DKI Jakarta, West Java and East Java, 9 provinces for cluster C2 and for cluster C3 as much as 20. This can be input to the government, the province of concern in the number of cases of AIDS.
\end{abstract}

Keywords: Maining Data, AIDS Disease, Clustering, K-medoid

\section{PENDAHULUAN}

Algoritma partitioning around medoids (PAM) yang sering dikenal dengan algoritma K-Medoid adalah sebuah algoritma yang merepresentasikan cluster yang dibentuk menggunakan medoids yang dapat menemukan kelompok cluster diantara semua objek data di dalam sebuh kelompok data. K-Medoid dapat mengelompokan kasus penyakit AIDS dimana masyarakat banyak menderita penyakit AIDS di setiap provinsi, kita dapat menemukan orang yang terkena penyakit AIDS, metode K-Medoid tidak menentukan nilai rata - rata dari objek dalam cluster sebagai titik acuan akan tetapi menggunakan median atau yang disebut Medoid.

Algoritma Clustering yaitu K-Medoid yang mana akan di kelompokan terlebih dahalu menggunakan Medoid sebelum menemukan cluster $k$ pada objek $n$. dimana Clustering adalah sebuah data mining yang memiliki alat bantu dalam mengelompokkan objek-objek ke dalam cluster, untuk kemudian dijadikan sebuah informasi dalam mengetahui penyakit AIDS yang berdasarakan setiap provinsi. Pemanfaatan data kasus AIDS dapat dilakukan untuk proses pengelompokan sesuai dengan informasi yang dimiliki sebuah data yang akurat sehingga dapat diketahui seberapa banyak kasus penyakit AIDS menurut provinsi yang ada di Indonesia. Sehingga proses pengelompokan dapat di implementasikan melalui metode clustering yang salah satu nya ialah metode $K$-medoid. Masyarakat sering sekali tidak peduli terhadap gejala awal yang di alami oleh penderita penyakit AIDS sehingga menimbulakan kematian pada penderita penyakit tersebut, Beberapa gejala awal infeksi tesebut dari yang ringan hingga yang akut adalah demam tinggi, muntah-muntah, nyeri pada sendi, pembengkakan kelenjarl getah bening, penyakit ini juga muncul dikulit dalam bentuk bintik yang juga menyerang mulut, saluran pencernaan dan paru-paru. Pencegahan AIDS dapat dilakukan tergantung dari tingkat pemahaman seseorang yang didasari oleh pengetahuan. Disini penulis memberikan solusi untuk mengelompokan kasus penyakit AIDS berdasarkan provinsi yang menggunakan Data Mining dengan metode K-Medoid Clustering. Karena K-Medoid dapat menemukan kelompok cluster di antara semua objek data di dalam sebuah data sehingga hasil dari penelitian ini dapat memberikan informasi kepada pihak pemerintah dalam mengurangi penyakit AIDS. Dan dapat menjadikan perhatian kepada pihak pemerintah dalam menangani khusus penyakit AIDS yang ada di provinsi Indonesia 


\section{TEORITIS}

\subsection{Data Mining}

Data mining adalah kegiatan menemukan pola yang menarik dari data dalam jumlah besar, data dapat disimpan dalam database, data warehouse, atau penyimpanan informasi lainnya [1][2] . Pola yang digunakan dalam data mining harus sangat mudah dipahami,baru dan bermanfaat.

Data Mining sering juga disebut Knowledge discovery in database(KDD), adalah kegiatan yang meliputi pengumpulan,pemakaian data historis untuk menemukan, pola atau hubungan dalam set data berukuran besar. Keluaran dari data mining ini bisa dipakai untuk memperbaiki pengambilan keputusan di masa depan.sehingga istilah pattern recognition jarang digunakan karena termasuk bagian dari data mining [3]

Beberapa peneliti memberikan nama lain untuk data mining sebagai ganti untuk istilah yang menurut mereka kurang tepat tersebut, diantara lain, ada yang menyebut dengan Knowledge Discovery in Data (KDD) [4].

\subsection{Algoritma K-Medoids}

Algoritma PAM sering dikenal dengan algoritma $k$-Medoids adalah sebuah algoritma yang merepresentasikan cluster yang dibentuk menggunakan medoids [5]. Cluster di bangun dengan menghitung kedekatan yang dimiliki antara medoid dengan objek non-medoid menggunakan distance measure. Jadi metode partisi masih dapat dilakukan berdasarkan prinsip meminimalkan jumlah dari ketidak miripan antara setiap objek dan medoid yang sesuai [6]

Beberapa langkah-langkah dalam perhitungan algoritma K-Medoids sebagai berikut:

1. Inisialisasi pusat cluster sebanyak $\mathrm{k}$ (jumlah cluster)

2. Alokasikan setiap data (objek) ke cluster terdekat menggunakan persamaan ukuran jarak Euclidian Distance dengan persamaan:

$$
d(i, j)=|| i-j||=\sqrt{\sum_{i=1}^{n}\left(i_{i}-j_{j}\right)} ; \mathrm{k}=1,2,3,
$$

Dimana:

$\mathrm{D}(\mathrm{i}, \mathrm{j})=$ jarak data ke $\mathrm{i}$ ke pusat cluster $\mathrm{j}$

$\mathrm{Ii}=$ data ke I atribut data ke I

$\mathrm{Ji}=$ titik pusat ke $\mathrm{J}$ pada atribut ke $\mathrm{i}$

3. Pilih secara acak objek pada masing-masing cluster sebagai kandidat medoid baru.

4. Hitung jarak setiap objek yang berada pada masing-masing cluster dengan kandidat medoids baru.

5. Hitung total simpangan $(\mathrm{S})$ dengan menghitung nilai total distance baru - total distance lama. Jika $\mathrm{S}<0$, maka tukar objek dengan data cluster untuk membentuk sekumpulan k objek baru sebagai medoids.

Ulangi langkah 3 sampai 5 hingga tidak terjadi perubahan medoids, sehingga didapatkan cluster beserta anggota cluster masing-masing

\section{ANALISA DAN PEMBAHASAN}

Metode $k$-medoids merupakan teknik partisi klasik clustering yang mengelompokkan data set dari $n$ objek ke dalam kelompok $k$ dikenal apriori. Metode ini menggunakan objek pada kumpulan objek untuk mewakili sebuah cluster. Objek yang terpilih untuk mewakili sebuah cluster disebut dengan medoid. Cluster di bangun dengan menghitung kedekatan yang dimiliki antara medoid dengan objek non-medoid. Berbeda dengan $k$-means, metode $k$ medoids menggunakan objek sebagai perwakilan (medoid) sebagai pusat cluster untuk setiap cluster, sedangkan $k$ means menggunakan nilai rata-rata (mean) sebagai pusat cluster. Diagram alir (flowchart) dari metode $k$-medoids clustering dapat dilihat pada gambar 1. 


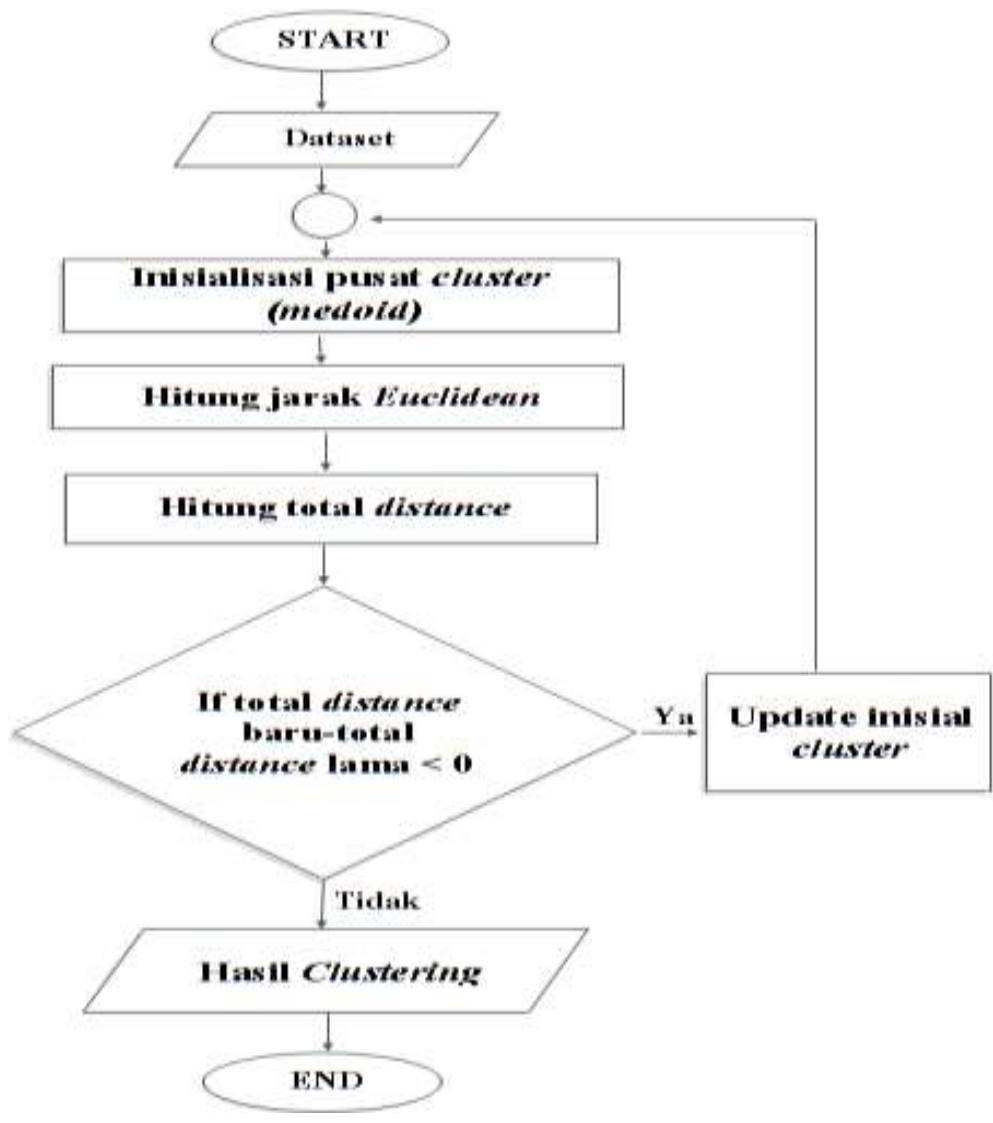

Gambar 1. Flowchart Metode K-Medoids Clustering

Gambar 1. merupakan langkah-langkah metode k-medoids clustering berdasarkan bagan alir (flowchart) dalam mengelompokkan data kaasus penyakit AIDS berdasarkan provinsi yang terdiri dari:

1. Menentukan jumlah data yang akan di cluster, dimana sampel data Kasus Penyakit AIDS yang digunakan dalam proses cluster tahun 2008-2012 yang terdiri dari 34 provinsi.

2. Menetapkan nilai $\mathrm{k}$ jumlah cluster data sebanyak 2 cluster $(k=2)$

3. Menentukan nilai centroid (pusat cluster) awal yang ditentukan secara random berdasarkan nilai variabel data yang di cluster sebanyak $k$ yang ditentukan sebelumnya.

4. Pilih secara acak objek pada masing-masing cluster sebagai kandidat medoid baru.

5. Hitung jarak setiap objek yang berada pada masing-masing cluster dengan kandidat medoid baru.

6. Hitung total simpangan $(S)$ dengan menghitung nilai total distance baru - total distance lama. Jika $S<0$, maka tukar objek dengan data cluster untuk membentuk sekumpulan $k$ objek baru sebagai medoid.

7. Ulangi langkah 3 sampai 5 hingga tidak terjadi perubahan medoid, sehingga didapatkan cluster beserta anggota cluster masing-masing.

Langkah - langkah dalam menyelesaikan perhitungan manual data mining menggunakan k-medoids clustering menggunakan 2 cluster yaitu:

1. Menentukan jumlah data yang akan di cluster

Tabel dibawah merupakan data yang akan di proses dengan metode $K$-Medoids Clustering.

Tabel 1. Data Penelitian

\begin{tabular}{lccccc}
\hline \multicolumn{1}{c}{ Provinsi } & $\begin{array}{c}\text { Jumlah } \\
\text { Kasus }\end{array}$ & $\begin{array}{c}\text { Kasus } \\
\text { Kumulatif }\end{array}$ & Meninggal & $\begin{array}{c}\text { Angka } \\
\text { Kumulatif Kasus }\end{array}$ & $\begin{array}{c}\text { Kasus } \\
\text { Baru }\end{array}$ \\
\hline Aceh & 43,5 & 104 & 11 & 1,0425 & 29,5 \\
Sumatera Utara & 542,75 & 515 & 104 & 4,2425 & 6 \\
Sumatera Barat & 328,75 & 615 & 85 & 7,055 & 69 \\
Riau & 422,25 & 766 & 124 & 7,7525 & 113,5 \\
Jambi & 207,5 & 324 & 52 & 7,34 & 42 \\
Sumatera Selatan & 195,25 & 291 & 36 & 2,7575 & 51,5 \\
Bengkulu & 96,5 & 152 & 22 & 5,605 & 12 \\
Lampung & 143,75 & 192 & 42 & 1,935 & 11 \\
Kepulauan Bangka Belitung & 106 & 183 & 15 & 9,9975 & 15 \\
Kepulauan Riau & 342 & 389,5 & 134 & 24,76 & 64,5
\end{tabular}




DKI Jakarta
Jawa Barat
Jawa Tengah
DI Yogyakarta
Jawa Timur
Banten
Bali
Nusa Tenggara Barat
Nusa Tenggara Timur
Kalimantan Barat
Kalimantan Tengah
Kalimantan Selatan
Kalimantan Timur
Sulawesi Utara
Sulawesi Tengah
Sulawesi Selatan
Sulawesi Tenggara
Gorontalo
Sulawesi Barat
Maluku
Maluku Utara
Papua Barat
Papua
Indonesia

$\begin{array}{ccc}3382,5 & 5708 & 505 \\ 3343,25 & 4018,5 & 609 \\ 839,5 & 2208,5 & 267 \\ 388,5 & 659 & 9 \\ 3301 & 5749 & 703 \\ 287,5 & 629,5 & 5 \\ 1467,25 & 2886 & 261 \\ 142,25 & 299 & 7 \\ 218,75 & 379 & 3 \\ 927,5 & 1484 & 12 \\ 37 & 93,5 & 3 \\ 26 & 80,5 & 5 \\ 11,25 & 173 & 10 \\ 255 & 506,5 & 73 \\ 11 & 60,5 & 6 \\ 468 & 1160 & 8 \\ 19,25 & 109,5 & 4 \\ 3 & 33,5 & 1 \\ 0 & 3 & 0 \\ 191,25 & 253,5 & 70 \\ 12,75 & 70 & 8 \\ 142,75 & 167 & 5 \\ 3144,5 & 3899,7245 & 473 \\ 21048 & 36383 & 4125\end{array}$

\begin{tabular}{ccc}
505 & 37,0525 & 885,5 \\
609 & 8,1875 & 197,5 \\
267 & 2,4225 & 605 \\
90 & 11,2875 & 137 \\
703 & 8,9325 & 671 \\
50 & 2,905 & 106,5 \\
261 & 41,3875 & 510 \\
71 & 3,2225 & 100 \\
34 & 4,885 & 33 \\
122 & 21,25 & 119,5 \\
3 & 1,695 & 25,5 \\
5 & 0,7675 & 22 \\
10 & 0,3625 & 18,5 \\
73 & 11,415 & 109 \\
6 & 0,4475 & 43 \\
88 & 5,685 & 167,5 \\
4 & 0,9025 & 46 \\
1 & 0,3225 & 10 \\
0 & 0 & 3 \\
70 & 14,195 & 60 \\
8 & 1,3325 & 38 \\
52 & 20,2175 & 44 \\
473 & 156,1325 & 620 \\
4125 & 9,09 & 4924 \\
\hline & &
\end{tabular}

2. Inisialisasi pusat cluster sebanyak 2 cluster dari data sampel. Untuk pemilihan setiap medoid dipilih secara acak. Seperti pada tabel 2.

Tabel 2. Medoid Awal

\begin{tabular}{ccccccc}
\hline No & Provinsi & $\begin{array}{c}\text { Jumlah } \\
\text { Kasus }\end{array}$ & $\begin{array}{c}\text { Kasus } \\
\text { Kumulatif }\end{array}$ & Meninggal & Angka kumulatif & Kasus Baru \\
\hline 1 & Lampung(C1) & 143.75 & 192 & 42 & 1.935 & 11 \\
2 & Bali(C2) & 1467.25 & 2886 & 261 & 41.3875 & 510 \\
\hline
\end{tabular}

3. Menghitung nilai jarak (cost) dengan persamaan Euclidian Distance: untuk menghitung jarak antara titik centroid dengan titik tiap objek menggunakan Euclidian Distance. Rumus untuk menghitung jarak menggunakan persamaan (2). Berikut adalah perhitungan jarak pada data penanganan kasus AIDS :

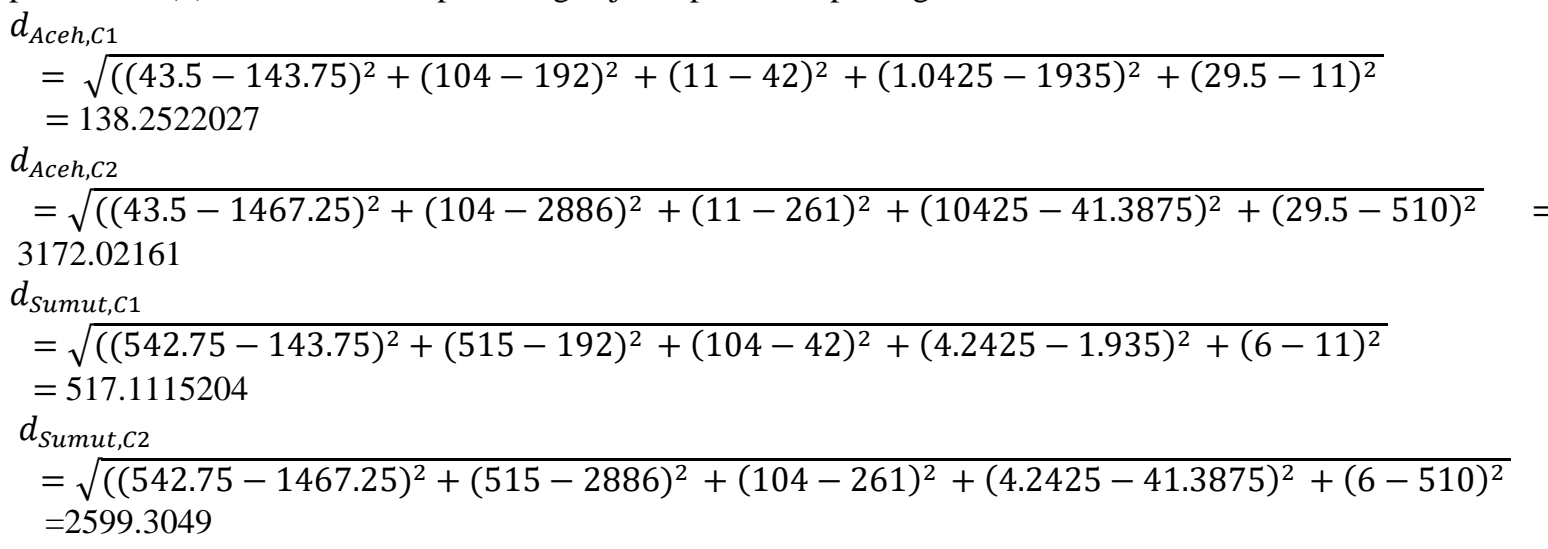

Hasil dari keseluruhan dapat dilihat pada tabel 3, sebagai berikut:

Tabel 3. Hasil Perhitungan Algoritma K-Medoids Iterasi ke-1

\begin{tabular}{lcccc}
\hline & \multicolumn{2}{c}{ Jarak Ke Medoid } & \multirow{2}{*}{ Terdekat } & \multirow{2}{*}{ Cluster yang diikuti } \\
\hline Pceh & C1 & C2 & & 1 \\
Sumatera Utara & 138,2522027 & 3172,02161 & 138,2522027 & 1 \\
Sumatera Barat & 517,1115204 & 2599,304907 & 517,1115204 & 1 \\
Riau & 467,3026609 & 2584,636731 & 467,3026609 & 1 \\
Jambi & 651,4164611 & 2400,722626 & 651,4164611 & 1 \\
Sumatera Selatan & 150,2606952 & 2900,80649 & 150,2606952 & 1
\end{tabular}




Bengkulu
Lampung
Kepulauan Bangka Belitung
Kepulauan Riau
DKI Jakarta
Jawa Barat
Jawa Tengah
DI Yogyakarta
Jawa Timur
Banten
Bali
Nusa Tenggara Barat
Nusa Tenggara Timur
Kalimantan Barat
Kalimantan Tengah
Kalimantan Selatan
Kalimantan Timur
Sulawesi Utara
Sulawesi Tengah
Sulawesi Selatan
Sulawesi Tenggara
Gorontalo
Sulawesi Barat
Maluku
Maluku Utara
Papua Barat
Papua
Jumlah
Total

$\begin{array}{cccc}65,2464091 & 3108,092102 & 65,2464091 & 1 \\ 0 & 3050,869835 & 0 & 1 \\ 48,40781348 & 3076,68379 & 48,40781348 & 1 \\ 300,1842861 & 2777,343893 & 300,1842861 & 1 \\ 6472,684706 & 3439,793287 & 3439,793287 & 2 \\ 5023,409807 & 2240,858539 & 2240,858539 & 2 \\ 2225,713717 & 929,3307182 & 929,3307182 & 2 \\ 544,2529575 & 2508,521043 & 544,2529575 & 1 \\ 6459,208705 & 3432,487065 & 3432,487065 & 2 \\ 470,3698049 & 2587,011348 & 470,3698049 & 1 \\ 3050,833984 & 0,5 & 0,5 & 2 \\ 142,0779985 & 2941,775113 & 142,0779985 & 1 \\ 202,8766928 & 2850,336635 & 202,8766928 & 1 \\ 1517,271711 & 1558,551056 & 1517,271711 & 1 \\ 151,0930842 & 3185,365137 & 151,0930842 & 1 \\ 166,6993568 & 3202,0871 & 166,6993568 & 1 \\ 137,8403887 & 3128,348015 & 137,8403887 & 1 \\ 349,2237755 & 2707,123884 & 349,2237755 & 1 \\ 193,0628788 & 3223,221936 & 193,0628788 & 1 \\ 1033,831436 & 2031,25578 & 1033,831436 & 1 \\ 158,1000587 & 3176,282237 & 158,1000587 & 1 \\ 215,910659 & 3255,774969 & 215,910659 & 1 \\ 241,2815922 & 3285,025797 & 241,2815922 & 1 \\ 96,67501021 & 2966,166538 & 96,67501021 & 1 \\ 184,2482714 & 3214,646204 & 184,2482714 & 4 \\ 46,41456998 & 3067,31837 & 46,41456998 & 1 \\ 4830,357747 & 1977,655532 & 1977,655532 & \\ 36370,50426 & 89514,95851 & & \\ 125885,4628 & & & 1\end{array}$

Setelah didapatkan hasil jarak dari setiap objek (cost) pada iterasi pertama maka lanjut ke iterasi 2. Kandidat medoid baru (non medoid) pada iterasi ke-2 dapat dilihat pada tabel 4 berikut:

\begin{tabular}{ccccccc}
\hline \multicolumn{7}{c}{ Tabel 4. Non Medoid } \\
No & Provinsi & $\begin{array}{c}\text { Jumlah } \\
\text { Kasus }\end{array}$ & $\begin{array}{c}\text { Kasus } \\
\text { Kumulatif }\end{array}$ & Meninggal & $\begin{array}{c}\text { Angka } \\
\text { kumulatif }\end{array}$ & $\begin{array}{c}\text { Kasus } \\
\text { Baru }\end{array}$ \\
\hline 1 & Papua(C1) & $3.144,50$ & 3.900 & 473 & 156,1325 & 620 \\
2 & Papua Barat(C2) & 142,75 & 167 & 52 & 20,2175 & 44 \\
\hline
\end{tabular}

Menempatkan kembali objek-objek non medoids ke dalam cluster yang paling dekat dengan medoids berdasarkan jarak Euclidean. Berikut adalah perhitungan jarak pada data penanganan kasus AIDS :

$$
\begin{aligned}
& d_{\text {Aceh }, \text { C1 }} \\
& \quad=\sqrt{(43.5-3.144,50)^{2}+(104-3.900)^{2}+(11-437)^{2}}+(1.0425-156,1325)^{2}+(29.5-620)^{2} \\
& =4960,861185 \\
& d_{\text {Aceh }, C 2} \\
& =\sqrt{(43.5-142,75)^{2}+(104-167)^{2}+(11-52)^{2}+(1.0425-20,2175)^{2}+(29.5-44)^{2}} \\
& =126,882054 \\
& d_{\text {Sumut }, C 1} \\
& \quad=\sqrt{(542,75-3.144,50)^{2}+(515-3.900)^{2}+(104-437)^{2}+(4,2425-156,1325)^{2}+(6-620)^{2}} \\
& =4331,47672 \\
& d_{\text {Sumut }, \text { } 2} \\
& =\sqrt{(542,75-142,75)^{2}+(515-167)^{2}+(104-52)^{2}+(4,2425-20,2175)^{2}+(6-44)^{2}} \\
& =534,3287383
\end{aligned}
$$

Hasil perhitungan jarak ke setiap non medoids baru, dapat dilihat pada tabel 5 berikut :

Tabel 5. Hasil perhitungan jarak ke setiap non medoids baru

\begin{tabular}{llll}
\hline \multirow{2}{*}{ Provinsi } & Jarak Ke Medoid & Terdekat & Cluster yang diikuti
\end{tabular}




\begin{tabular}{|c|c|c|c|c|}
\hline Aceh & 4960,861185 & 126,882054 & 126,882054 & 2 \\
\hline Sumatera Utara & 4331,47672 & 534,3287383 & 534,3287383 & 2 \\
\hline Sumatera Barat & 4381,144402 & 487,0018623 & 487,0018623 & 2 \\
\hline Riau & 4198,935549 & 668,6755108 & 668,6755108 & 2 \\
\hline Jambi & 4684,574571 & 170,3273099 & 170,3273099 & 2 \\
\hline Sumatera Selatan & 4717,930879 & 136,9577092 & 136,9577092 & 2 \\
\hline Bengkulu & 4892,002864 & 67,20602768 & 67,20602768 & 2 \\
\hline Lampung & 4830,335433 & 46,36000222 & 46,36000222 & 2 \\
\hline \multicolumn{5}{|l|}{ Kepulauan Bangka } \\
\hline Belitung & 4862,522591 & 62,91471132 & 62,91471132 & 2 \\
\hline Kepulauan Riau & 4540,551931 & 310,3719693 & 310,3719693 & 2 \\
\hline DKI Jakarta & 1847,20514 & 6489,362294 & 1847,20514 & 1 \\
\hline Jawa Barat & 521,8844747 & 5040,897908 & 521,8844747 & 1 \\
\hline Jawa Tengah & 2870,462171 & 2239,295754 & 2239,295754 & 2 \\
\hline DI Yogyakarta & 4301,06645 & 559,099327 & 559,099327 & 2 \\
\hline Jawa Timur & 1876,591598 & 6476,932142 & 1876,591598 & 1 \\
\hline Banten & 4395,83103 & 488,9489085 & 488,9489085 & 2 \\
\hline Bali & 1977,682378 & 3067,301366 & 1977,682378 & 1 \\
\hline Nusa Tenggara Barat & 4736,508176 & 145,5724219 & 145,5724219 & 2 \\
\hline Nusa Tenggara Timur & 4638,547092 & 226,7561147 & 226,7561147 & 2 \\
\hline Kalimantan Barat & 3338,043283 & 1536,540901 & 1536,540901 & 2 \\
\hline Kalimantan Tengah & 4974,141372 & 140,2556434 & 140,2556434 & 2 \\
\hline Kalimantan Selatan & 4991,220724 & 155,5124272 & 155,5124272 & 2 \\
\hline Kalimantan Timur & 4930,128457 & 141,9039148 & 141,9039148 & 2 \\
\hline Sulawesi Utara & 4506,11218 & 364,1625448 & 364,1625448 & 2 \\
\hline Sulawesi Tengah & 5013,401049 & 176,7891835 & 176,7891835 & 2 \\
\hline Sulawesi Selatan & 3878,80985 & 1052,907436 & 1052,907436 & 2 \\
\hline Sulawesi Tenggara & 4970,589224 & 145,8205463 & 145,8205463 & 2 \\
\hline Gorontalo & 5043,399141 & 203,7280627 & 203,7280627 & 2 \\
\hline Sulawesi Barat & 5069,628925 & 228,1826238 & 228,1826238 & 2 \\
\hline Maluku & 4744,80739 & 102,1421583 & 102,1421583 & 2 \\
\hline Maluku Utara & 5005,376351 & 169,2917769 & 169,2917769 & 2 \\
\hline Papua Barat & 4844,68933 & 0,25 & 0,25 & 2 \\
\hline Papua & 0,25 & 4844,73278 & 0,25 & 1 \\
\hline Jumlah & 134876,7119 & 36607,41213 & & \\
\hline Total & 171484,124 & & & \\
\hline
\end{tabular}

4. Menghitung nilai $S$ dengan persamaan 2.1. sebagai berikut:

$S=$ total cost baru - total cost lama

Dengan : $S=$ Selisih

Total cost baru $=$ total cost non medoids

Total cost lama = total cost untuk medoids

Sehingga diperoleh:

$S=171484,124-125885,4628=108737,0504$

5. Karena nilai $\mathrm{S}>0$ maka proses pengklasteran dihentikan. Sehingga diperoleh anggota tiap klaster sebagai berikut.

Tabel 6. Hasil pengklasteran data dengan $k$-medoids clustering

\begin{tabular}{|c|c|c|c|c|c|}
\hline \multirow{2}{*}{ No. } & \multirow{2}{*}{ Data ke i } & \multicolumn{2}{|c|}{ Jarak ke medoids } & \multirow{2}{*}{ Terdekat } & \multirow{2}{*}{$\begin{array}{c}\text { Cluster } \\
\text { yang }\end{array}$} \\
\hline & & $\mathrm{C} 1$ & $\mathrm{C} 2$ & & \\
\hline 1. & Aceh & 4960,861185 & 126,882054 & 126,882054 & 2 \\
\hline 2. & Sumatera Utara & 4331,47672 & 534,3287383 & 534,3287383 & 2 \\
\hline 3. & Sumatera Barat & 4381,144402 & 487,0018623 & 487,0018623 & 2 \\
\hline 4. & Riau & 4198,935549 & 668,6755108 & 668,6755108 & 2 \\
\hline 5. & Jambi & 4684,574571 & 170,3273099 & 170,3273099 & 2 \\
\hline 6. & Sumatera Selatan & 4717,930879 & 136,9577092 & 136,9577092 & 2 \\
\hline 7. & Bengkulu & 4892,002864 & 67,20602768 & 67,20602768 & 2 \\
\hline 8. & Lampung & 4830,335433 & 46,36000222 & 46,36000222 & 2 \\
\hline 9. & Kepulauan Bangka Belitung & 4862,522591 & 62,91471132 & 62,91471132 & 2 \\
\hline 10. & Kepulauan Riau & 4540,551931 & 310,3719693 & 310,3719693 & 2 \\
\hline 11. & DKI Jakarta & 1847,20514 & 6489,362294 & 1847,20514 & 1 \\
\hline 12. & Jawa Barat & 521,8844747 & 5040,897908 & 521,8844747 & 1 \\
\hline
\end{tabular}




$\begin{array}{ll}\text { 13. } & \text { Jawa Tengah } \\ \text { 14. } & \text { DI Yogyakarta } \\ \text { 15. } & \text { Jawa Timur } \\ \text { 16. } & \text { Banten } \\ \text { 17. } & \text { Bali } \\ \text { 18. } & \text { Nusa Tenggara Barat } \\ \text { 19. } & \text { Nusa Tenggara Timur } \\ \text { 20. } & \text { Kalimantan Barat } \\ \text { 21. } & \text { Kalimantan Tengah } \\ \text { 22. } & \text { Kalimantan Selatan } \\ \text { 23. } & \text { Kalimantan Timur } \\ \text { 24. } & \text { Sulawesi Utara } \\ \text { 25. } & \text { Sulawesi Tengah } \\ \text { 26. } & \text { Sulawesi Selatan } \\ \text { 27. } & \text { Sulawesi Tenggara } \\ \text { 28. } & \text { Gorontalo } \\ \text { 29. } & \text { Sulawesi Barat } \\ \text { 30. } & \text { Maluku } \\ \text { 31. } & \text { Maluku Utara } \\ \text { 32. } & \text { Papua Barat } \\ \text { 33. } & \text { Papua }\end{array}$

$\begin{array}{cccc}2870,462171 & 2239,295754 & 2239,295754 & 2 \\ 4301,06645 & 559,099327 & 559,099327 & 2 \\ 1876,591598 & 6476,932142 & 1876,591598 & 1 \\ 4395,83103 & 488,9489085 & 488,9489085 & 2 \\ 1977,682378 & 3067,301366 & 1977,682378 & 1 \\ 4736,508176 & 145,5724219 & 145,5724219 & 2 \\ 4638,547092 & 226,7561147 & 226,7561147 & 2 \\ 3338,043283 & 1536,540901 & 1536,540901 & 2 \\ 4974,141372 & 140,2556434 & 140,2556434 & 2 \\ 4991,220724 & 155,5124272 & 155,5124272 & 2 \\ 4930,128457 & 141,9039148 & 141,9039148 & 2 \\ 4506,11218 & 364,1625448 & 364,1625448 & 2 \\ 5013,401049 & 176,7891835 & 176,7891835 & 2 \\ 3878,80985 & 1052,907436 & 1052,907436 & 2 \\ 4970,589224 & 145,8205463 & 145,8205463 & 2 \\ 5043,399141 & 203,7280627 & 203,7280627 & 2 \\ 5069,628925 & 228,1826238 & 228,1826238 & 2 \\ 4744,80739 & 102,1421583 & 102,1421583 & 2 \\ 5005,376351 & 169,2917769 & 169,2917769 & 2 \\ 4844,68933 & 0,25 & 0,25 & 2 \\ 0,25 & 4844,73278 & 0,25 & 1\end{array}$

Dalam melakukan validasi data perhitungan algoritma harus menghasilkan hasil akhir berupa pengelompokkan dengan 2 cluster, serta data yang digunakan merupakan data yang valid dan sama dengan yang dipakai pada tools rapidminer 5.3. Berikut ditampilkan hasil yang didapatkan dari perhitungan algotirma dan pengujian pada rapidminer 5.3, pada tabel 7 dibawah ini.

Tabel 7. Perbandingan Hasil Akhir K-Medoids

\begin{tabular}{|c|c|c|}
\hline Provinsi & Perhitungan Algoritma K-Medoids & Pengujian Dengan Rapidminer 5.3 \\
\hline Aceh & cluster_2 & cluster_2 \\
\hline Sumatera utara & cluster_2 & cluster_2 \\
\hline Sumatera barat & cluster_2 & cluster_2 \\
\hline Riau & cluster_2 & cluster_2 \\
\hline Jambi & cluster_2 & cluster_2 \\
\hline Sumatera selatan & cluster_2 & cluster_2 \\
\hline Bengkulu & cluster_2 & cluster_2 \\
\hline Lampung & cluster_2 & cluster_2 \\
\hline Kep. Bangka belitung & cluster_2 & cluster_2 \\
\hline Kep. Riau & cluster_2 & cluster_2 \\
\hline Dki jakarta & cluster_1 & cluster_1 \\
\hline Jawa barat & cluster_1 & cluster_1 \\
\hline Jawa tengah & cluster_2 & cluster_2 \\
\hline Di yogyakarta & cluster_2 & cluster_2 \\
\hline Jawa timur & cluster_1 & cluster_1 \\
\hline Banten & cluster_2 & cluster_2 \\
\hline Bali & cluster_1 & cluster_1 \\
\hline Nusa tenggara barat & cluster_2 & cluster_2 \\
\hline Nusa tenggara timur & cluster_2 & cluster_2 \\
\hline Kalimantan barat & cluster_2 & cluster_2 \\
\hline Kalimantan tengah & cluster_2 & cluster_2 \\
\hline Kalimantan selatan & cluster_2 & cluster_2 \\
\hline Kalimantan timur & cluster_2 & cluster_2 \\
\hline Kalimantan utara & cluster 2 & cluster 2 \\
\hline Sulawesi utara & cluster_2 & cluster_2 \\
\hline Sulawesi tengah & cluster_2 & cluster_2 \\
\hline Sulawesi selatan & cluster_2 & cluster_2 \\
\hline Sulawesi tenggara & cluster_2 & cluster_2 \\
\hline Gorontalo & cluster_2 & cluster_2 \\
\hline Sulawesi barat & cluster_2 & cluster_2 \\
\hline
\end{tabular}




Maluku
Maluku utara
Papua barat
Papua
Hasil

Maluku

Hasil cluster_2
cluster_2
cluster_2
cluster_1
cluster_1
cluster_2 cluster 2

cluster_2

cluster_2

cluster_1

11

23

\section{KESIMPULAN}

Berdasarkan pembahasan diatas dapat disimpulkan bahwa :

1. Penerapan Data Mining menggunakan algoritma K-MEDOIDS untuk mengelompokkan kasus penyakit AIDS menurut provinsi dengan data uji sebanyak 33 provinsi dengan menggunakan dua cluster. cluster 1 (nilai terendah) sebanyak 5, cluster 2 (nilai tinggi) sebanyak 28 .

2. Pengujian data pada Rapiminer 5.3 dengan menggunakan K-MEDOIDS dapat menampilkan dua kelas dari hasil klastering dengan persentase keakuratan sebesar $100 \%$.

\section{REFERENCES}

[1] G. Abdillah, F. A. Putra, And F. Renaldi, "Penerapan Data Mining Pemakaian Air Pelanggan Untuk Menentukan Klasifikasi Potensi Pemakaian Air Pelanggan Baru Di Pdam Tirta Raharja Menggunakan Algoritma K-Means," Vol. 2016, No. Sentika, Pp. 18-19, 2016.

[2] C. Fadlan, S. Ningsih, And A. P. Windarto, "Penerapan Metode Naïve Bayes Dalam Klasifikasi Kelayakan Keluarga Penerima Beras Rastra,” Jutim, Vol. 3, No. 1, Pp. 1-8, 2018.

[3] W. Muslehatin, M. Ibnu, And Mustakim, "Penerapan Naïve Bayes Classification Untuk Klasifikasi Tingkat Kemungkinan Obesitas Mahasiswa Sistem Informasi Uin Suska Riau,” Semin. Nas. Teknol. Informasi, Komun. Dan Ind., Pp. 18-19, 2017.

[4] R. 0kta And N. Warnia, "K-Means Analysis Klasterisasi Kasus Hiv / Aids Di Indonesia K-Means Analysis Klasterisasi Kasus Hiv / Aids Di Indonesia," No. February, 2017.

[5] Y. H. Chrisnanto And G. Abdillah, "Penerapan Algoritma Partitioning Around Medoids ( Pam ) Clustering Untuk Melihat Gambaran Umum Kemampuan,” Vol. 2015, No. Sentika, Pp. 444-448, 2015.

[6] B. D. Satoto, "Pendidikan Menggunakan Partition Around Medoids Dan," Vol. 1, No. 1, Pp. 17-24, 2015. 